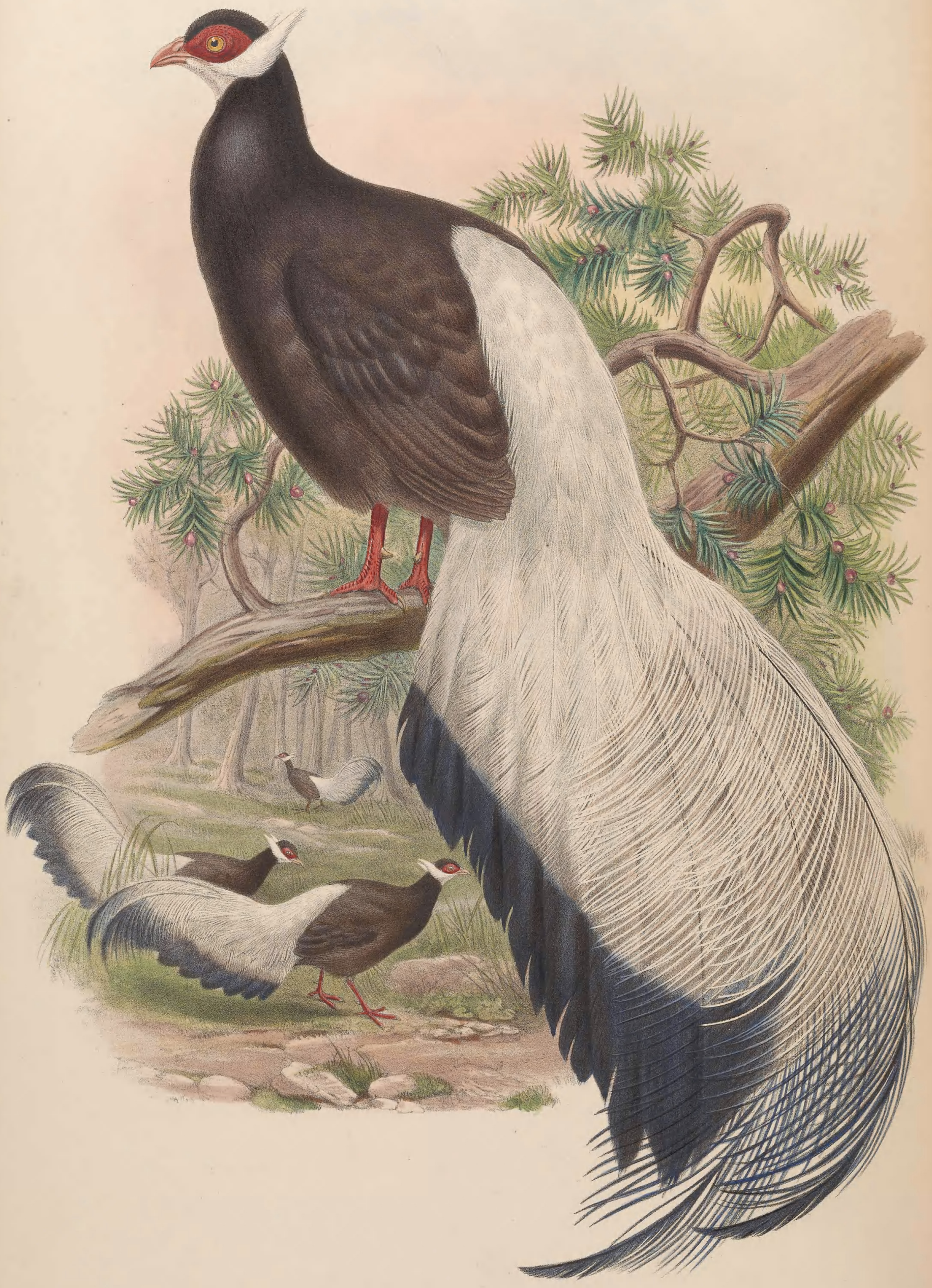




\section{CROSSOP'TILON AURITUM.}

Chinese Crossoptilon.

Phasianus auritus, Pall. Zoog. Rosso-Asiat., tom. ii. p. 86.

Crossoptilon mantchuricum, Swin. in Proc. of Zool. Soc., 1862, p. 287.

- auritum, Sclat. in Proc. of Zool. Soc., 1863, p. 118.-Milne-Edw. Nouv. Arch. du Mus., Bull. i. p. 14. pl. 1.-Bonap. Tab. par. du Gall., Compt. Rend. de l'Acad. Sci., tom. xlii. p. 879.-Newt. Zool. Rev., vol. iii., 1866, p. 107.

Crossoptilum auritum, Newt. Zool. Rev., vol. ii., 1865, p. 125.

The knowledge of the existence of the very fine bird figured on the opposite plate may almost be regarded as one of the results of our conquests in China; for, beyond the somewhat vague description given in Pallas's celebrated 'Zoographia Rosso-Asiatica,' it was previously unknown, whereas we are now aware that it is to be met with around Pekin, and it is often exposed for sale as an article of food in the markets of the northern part of the Celestial Empire. Even the Russian naturalists must have been taken by surprise when this was discovered to be the case; for I believe that so recently as five years prior to that in which I am now writing (1870) there was not a perfect specimen in the celebrated Museum at St. Petersburg, and certainly not in those of Berlin, Leyden, or Paris. Now, however, all have been or may be supplied with skins from Northern China or of specimens from the menageries of Europe, few of which, I presume, are destitute of living examples.

So tame is the disposition of this bird, and so readily does it breed in captivity, that, in these respects, it may be fairly compared with the common Fowl. In the gardens of the Zoological Society in the Regent's Park, many may be seen, either occupying the aviaries, moving about in a semidomesticated state, or roosting at night on the large trees of the Gardens apart from the enclosures. In confirmation of these assertions, I may give the following note, obligingly furnished me by Dr. Sclater, the Society's excellent Secretary :-

"The first living Crossoptilons acquired by the Society were two males, brought by Mr. Dudley E. Saurin from Pekin in 1866, and presented by him to the Society on the 15th of July in that year. On the 10th of the following November, we purchased, from the Jardin d'Acclimatation of Paris, two females, which had been bred in that establishment during the previous summer. Our two pairs thus formed bred in the Society's Gardens the following spring; and on the 26th of May, 1867, the first hatch, of seven young ones, was produced. On the 14th of June a second brood, of nine young ones, saw the light. In the following year (1868) two broods were likewise produced-one, on the 21st of May, of ten, and the other, on the 13th of June, of eight young ones. Incubation, as in the case of most of our foreign Pheasants, was effected by hens of the domestic Fowl. We are at present rather short of males of this Pheasant, but are offering females for sale at the very moderate price of $£ 15$ each. Seeing that we purchased our first two females for $£ 50$ each, it will be evident that the stock of this bird in Europe must have considerably augmented during the last three years."

Mr. Saurin, to whom we were indebted for the first specimens of this fine bird received alive, kindly drew up some notes upon this species and other Pheasants occurring in the neighbourhood of Pekin, which will be found in the Zoological Society's 'Proceedings' for 1866, p. 436, in which he says :-

"Pallas's Eared Pheasant (Crossoptilon auritum) is rarely seen in the Pekin market. The bird is found in the mountains to the north-west of that city, within the Great Wall, and about one hundred miles distant. The place is well known for its coal-mines, and has frequently been visited by Europeans-amongst others by the French Minister, M. Berthéney, the French Missionaries, and several of our Student Interpreters. M. Berthéney, who is a sportsman and fond of natural history, thinks that, taking into consideration the comparative tameness of the bird, and the fact that, since Europeans have come to Pekin, the peasants have always found a good market for the nests, this rare bird, which, so far as we know, is only to be found at this one spot, cannot fail soon to become extinct. Chinese guides, it is true, have assured me that it is to be found in the Wei-chung or Imperial bunting-grounds; but no reliance can be placed on their statements, even if the bird were called by the same name in so very distant a part of the country.

"The Chinese name is Ho-chi, either 'River-fowl' or 'Fire-fowl.' The translation depends on the character; and the peasants, who give it the name, know notling of characters, while the students, who know characters, are quite ignorant of natural history.

"Pallas's Pheasant is never brought by Mongols, or frozen; therefore " mantchuricum" (the name applied to it by Mr. Swinhoe) is a misnomer. The hen lays towards the end of May; the eggs are larger 
than those of a common Fowl, and, so far as I recollect, rather bluish in tint. The Chinese, who bring these birds in, feed them with a kind of millet-cake; they are also very fond of barley, which is grown in abundance in the mountain-valleys."

We learn from Dr. Lamprey's notes on the gallinaceous birds observed by him in China, that this is one of the four kinds of Pheasants he has seen in the markets of Tien-Tsin, the uninterrupted cold of winter allowing of their being brought in large numbers from remote places, and preserving them fit for use until the spring. "The meat of this kind of Pheasant," says the Doctor, " is exceedingly delicate, and the body is nearly as bulky as that of a small-sized Turkey." (Proc. Zool. Soc., 1862, p. 221.)

To test the quality of the flesh of the Crossoptiton, I had a female, that had been killed by a male in the Zoological Gardens, cooked in the ordinary way. It weighed over five pounds. The pectoral muscles were white, like those of the Common Pheasant, and equal in flavour; but the legs and thighs, which were very large in comparison with the size of the bird, were coarse, brown, and less palatable.

Mr. Bartlett states that these birds breed when only one year old, that the young birds assume the adult plumage at the first moult, that the sexes are exactly similar, and that they are remarkably hardy and extremely tame. (Proc. Zool. Soc., 1868, p. 115.)

Mons. Armand David, the French Missionary at Pekin, to whom the authorities of the Museum of Natural History at Paris are indebted for the specimens of Crossoptilon auritum in their collection, "met with these rare birds for the first time in July 1863, in the northern valley of a high mountain, about fifteen leagues to the west of Pekin. The female only differs from the male in being slightly smaller in size, and in having the spurs but little developed; and the nuptial plumage and that of winter are identical. Captured and placed in an aviary, these birds become gentle and familiar; their voice is varied, but closely resembles that of the domestic Fowl. The Chinese know the bird by the name of Ho-ki or Gho-hy. It dwells in small numbers in the most wooded places of the mountains. Three specimens killed in July had their crops filled with the leaves of Cytisus; while those procured in winter contained nuts, various kernels, leaves of mugwort, ferns, and, above all, roots of orchids and other succulent plants, coleoptera, worms, and caterpillars. When I killed the three adults above mentioned, there were four other old ones and fifteen young, all feeding together in a neighbouring field. Were they two families united ? They perch readily, and carry their tails elevated, like the common Fowl." (Nouv. Archiv. du Mus. d'Hist. Nat., Bull., tom. i. p. 13.)

The male has the short, velvety, and partially curled feathers clothing the head deep glossy black ; sides of the head devoid of feathers, and of a deep blood-red, below which is a conspicuous lengthened tuft of silvery white feathers directed backwards and upwards; chin and throat silvery white, tinged with grey ; neck and the anterior portion of both the upper and under surfaces of the body deep, glossy, purplish black, gradually becoming paler on the latter, until it fades into leaden grey on the vent and thighs, and into a lighter grey on the under tail-coverts; on the former, or upper surface, the purplish black becomes of a hair-brown on the upper part of the back and wings; lower part of the back, rump, and upper tail-coverts hoary grey; all the tail-feathers grey at the base and purplish blue on their apical portion ; irides light orange; bill fleshy; feet sealing-wax red; nails horny.

Total length 33 inches, bill $1 \frac{3}{4}$, wing $12 \frac{1}{4}$, tail 17 , tarsi 4 .

The figure is about two-thirds of the natural size. 


\section{$2 \mathrm{BHL}$ Biodiversity Heritage Library}

Gould, John. 1870. "Chinese Crossoptilon, Crossoptilon auritum [PI. 22]." The Birds of Asia 7(XXII), -. https://doi.org/10.5962/p.323306.

View This Item Online: https://www.biodiversitylibrary.org/item/122491

DOI: https://doi.org/10.5962/p.323306

Permalink: https://www.biodiversitylibrary.org/partpdf/323306

\section{Holding Institution}

Smithsonian Libraries

\section{Sponsored by}

Smithsonian Institution Libraries

\section{Copyright \& Reuse}

Copyright Status: Not in copyright

This document was created from content at the Biodiversity Heritage Library, the world's largest open access digital library for biodiversity literature and archives. Visit BHL at https://www.biodiversitylibrary.org. 